\title{
Berberine and Obatoclax Inhibit SARS-Cov-2 Replication in Primary Human Nasal Epithelial Cells In Vitro
}

\author{
Finny S. Varghese ${ }^{1,+}{ }^{+}$Esther van Woudenbergh ${ }^{2,3}{ }^{(D}$, Gijs J. Overheul ${ }^{1}\left({ }^{(}\right.$, Marc J. Eleveld $^{2}{ }^{(}$, Lisa Kurver ${ }^{4}$, \\ Niels van Heerbeek ${ }^{5}$, Arjan van Laarhoven ${ }^{4}{ }^{\oplus}$, Pascal Miesen ${ }^{1}$, Gerco den Hartog ${ }^{3} \mathbb{D}$, Marien I. de Jonge ${ }^{2}$ and \\ Ronald P. van Rij ${ }^{1, *(1)}$
}

1 Department of Medical Microbiology, Radboud Institute for Molecular Life Sciences, Radboud University Medical Center, 6500 HB Nijmegen, The Netherlands; finny.varghese@radboudumc.nl (F.S.V.); gijs.overheul@radboudumc.nl (G.J.O.); pascal.miesen@radboudumc.nl (P.M.)

2 Section Paediatric Infectious Diseases, Laboratory of Medical Immunology, Radboud Institute for Molecular Life Sciences, Radboud University Medical Center, 6500 HB Nijmegen, The Netherlands; esther.van.woudenbergh@rivm.nl (E.v.W.); Marc.Eleveld@radboudumc.nl (M.J.E.); marien.dejonge@radboudumc.nl (M.I.d.J.)

3 Centre for Immunology of Infectious Diseases and Vaccines, National Institute for Public Health and the Environment, 3721 MA Bilthoven, The Netherlands; Gerco.den.hartog@rivm.nl

4 Department of Internal Medicine, Radboud University Medical Center, 6500 HB Nijmegen, The Netherlands; Lisa.Kurver@radboudumc.nl (L.K.); arjan.vanlaarhoven@radboudumc.nl (A.v.L.)

check for updates

Citation: Varghese, F.S.; van Woudenbergh, E.; Overheul, G.J.; Eleveld, M.J.; Kurver, L.; van Heerbeek, N.; van Laarhoven, A.; Miesen, P.; den Hartog, G.; de Jonge, M.I.; et al. Berberine and Obatoclax Inhibit SARS-Cov-2 Replication in Primary Human Nasal Epithelial Cells In Vitro. Viruses 2021, 13, 282. https://doi.org/10.3390/v13020282

Academic Editors: Luiz

Martinez-Sorbido and Fernando Almazan Toral

Received: 21 January 2021

Accepted: 8 February 2021

Published: 11 February 2021

Publisher's Note: MDPI stays neutral with regard to jurisdictional claims in published maps and institutional affiliations.

Copyright: (c) 2021 by the authors. Licensee MDPI, Basel, Switzerland. This article is an open access article distributed under the terms and conditions of the Creative Commons Attribution (CC BY) license (https:// creativecommons.org/licenses/by/ $4.0 /)$.
5 Department of Otolaryngology, Head and Neck Surgery, Radboudumc, 6500 HB Nijmegen, The Netherlands; niels.vanheerbeek@radboudumc.nl

* Correspondence: ronald.vanrij@radboudumc.nl

+ Current Address: uniQure biopharma B.V., 1105 BE Amsterdam, The Netherlands.

\begin{abstract}
Severe acute respiratory syndrome coronavirus 2 (SARS-CoV-2) emerged as a new human pathogen in late 2019 and it has infected over 100 million people in less than a year. There is a clear need for effective antiviral drugs to complement current preventive measures, including vaccines. In this study, we demonstrate that berberine and obatoclax, two broad-spectrum antiviral compounds, are effective against multiple isolates of SARS-CoV-2. Berberine, a plant-derived alkaloid, inhibited SARS-CoV-2 at low micromolar concentrations and obatoclax, which was originally developed as an anti-apoptotic protein antagonist, was effective at sub-micromolar concentrations. Time-of-addition studies indicated that berberine acts on the late stage of the viral life cycle. In agreement, berberine mildly affected viral RNA synthesis, but it strongly reduced infectious viral titers, leading to an increase in the particle-to-pfu ratio. In contrast, obatoclax acted at the early stage of the infection, which is in line with its activity to neutralize the acidic environment in endosomes. We assessed infection of primary human nasal epithelial cells that were cultured on an air-liquid interface and found that SARS-CoV-2 infection induced and repressed expression of specific sets of cytokines and chemokines. Moreover, both obatoclax and berberine inhibited SARS-CoV-2 replication in these primary target cells. We propose berberine and obatoclax as potential antiviral drugs against SARS-CoV-2 that could be considered for further efficacy testing.
\end{abstract}

Keywords: coronavirus; COVID-19; antiviral compounds

\section{Introduction}

Coronaviruses form a group of respiratory viruses in the order Nidovirales that possess a positive-sense RNA genome of approximately $30 \mathrm{~kb}$ [1]. Two coronaviruses of zoonotic origin caused significant outbreaks in the near past, severe acute respiratory syndrome coronavirus (SARS-CoV) [2,3] and Middle Eastern respiratory syndrome coronavirus (MERS-CoV) [4]. In late 2019, a new coronavirus that was closely related to SARS-CoV emerged in Wuhan, China, and rapidly spread across the globe. As of today, more than 100 
million SARS-CoV-2 cases have been confirmed worldwide, but the total number may be up to 20 times higher due to asymptomatic and undetected cases [5,6] (WHO Coronavirus Disease Dashboard, https: / / covid19.who.int/, accessed on 07 February 2021).

SARS-CoV-2 infects epithelial cells in the nasal and oral cavities via binding of the spike protein to the ACE2 receptor [7]. The spike glycoprotein requires cleavage by the cellsurface protease TMPRSS2 in order to convert it into an active form, allowing for fusion at the plasma membrane [7-10]. Alternatively, in permissive cells lacking TMPRSS2, receptor binding is most likely followed by dynamin and clathrin-mediated endocytosis of the virus particle into endosomal compartments [11]. Acidification of these compartments leads to the activation of cathepsin- $\mathrm{B} / \mathrm{L}$ proteases that cleave the spike protein, initiating membrane fusion and release of the encapsidated viral RNA into the cytoplasm [12-14]. Upon nucleocapsid disassembly, the viral positive-sense RNA genome is translated into two open reading frames that encode for several non-structural proteins (reviewed in [15-17]). These proteins constitute the machinery that replicates the viral RNA and transcribes subgenomic RNAs that code for viral structural proteins and several accessory proteins [16]. Newly formed viral genomic RNA is coated with nucleocapsid proteins, which interact with the structural proteins, resulting in budding into, and transit through, the ER-Golgi network and the release of mature viral particles through exocytosis [16,17]. The virus then spreads to the lower respiratory tract and infects alveolar type-II pneumocytes in the lungs, where a severe infection can lead to acute respiratory distress syndrome [18].

A year into the COVID-19 pandemic, there has been an unprecedented fast development of vaccines [19], as well as study of antiviral or adjunctive host-directed therapy. However, apart from dexamethasone [20], none have been proved effective. There is a clear need for improved antiviral therapy, as preventive measures, including vaccines, are unlikely to curb the epidemic alone. This could be applied either preventively, or after symptom development.

In this study, we assessed the plant-based alkaloid berberine and obatoclax, an anticancer drug that has proven safe in clinical trials, as possible antiviral candidates against SARS-CoV-2. Berberine (BBR) [21-23] and obatoclax (OLX) [24,25] have both broad-spectrum antiviral activity against a range of different viruses, including herpes simplex virus, influenza A virus, chikungunya virus, and Zika virus. We show that these compounds are effective against two different isolates of SARS-CoV-2 at low micromolar concentrations with promising selectivity indices. Antiviral activity was observed in Vero E6 cells as well as in physiologically relevant nasal epithelial cells that are cultured on an air-liquid interface. We propose these compounds for further assessment as antiviral agents against SARS-CoV-2.

\section{Materials and Methods}

2.1. Cells

African green monkey Vero E6 (ATCC CRL-1586) and Vero FM (ATCC CCL-81) kidney epithelial cells were grown in Dulbecco's modified Eagle medium containing $4.5 \mathrm{~g} / \mathrm{L}$ glucose and L-glutamine (Gibco, Thermo Fisher Scientific, Waltham, MA), which was supplemented with $10 \%$ fetal calf serum (FCS, Sigma Aldrich), $100 \mu \mathrm{g} / \mathrm{mL}$ streptomycin, and $100 \mathrm{U} / \mathrm{mL}$ penicillin (Gibco). The cells were maintained at $37^{\circ} \mathrm{C}$ with $5 \% \mathrm{CO}_{2}$.

Primary epithelial cells were derived from post-operative residual tissue from the posterior nasal septum of a 17-year-old male, which was obtained after informed consent, according to the principles of the declaration of Helsinki. The patient had a fully normal nasal epithelium, was SARS-CoV-2 negative, and had no history of allergy, (chronic) rhinosinusitis, or other mucosal disease. A single cell suspension was made by incubating the tissue in Hank's Balanced Salt Solution (Gibco) with $1 \mathrm{mg} / \mathrm{mL}$ collagenase from clostridium histolyticum (Sigma-Aldrich, St. Louis, MO) and $0.02 \mathrm{mg} / \mathrm{mL}$ DNase 1 (SigmaAldrich) for $2 \mathrm{~h}$ at $37^{\circ} \mathrm{C}$. The cell suspension was filtered through a $70 \mu \mathrm{m}$ cell strainer and the flow-through was collected. The cells were cultured and expanded in PneumaCultEx Basal plus Medium with supplements (Stemcell Technologies, Vancouver, Canada), 
$0.48 \mu \mathrm{g} / \mathrm{mL}$ hydrocortisone (Stemcell), and $100 \mu \mathrm{g} / \mathrm{mL}$ streptomycin and $100 \mathrm{U} / \mathrm{mL}$ penicillin (Lonza, Basel, Switzerland), according to the manufacturer's protocol (Stemcell). 50,000 primary nasal epithelial cells were seeded on $0.4 \mu \mathrm{m}$ pore polyester membrane inserts (Corning) and expanded for one week in PneumaCult-Ex Basal plus Medium at $37^{\circ} \mathrm{C}$ and $5 \% \mathrm{CO}_{2}$. When the cells had formed a tight epithelial layer, they were cultured on an air-liquid interface by discarding the apical medium and adding PneumaCult-ALI Basal Medium with supplements (Stemcell), $4 \mu \mathrm{g} / \mathrm{mL}$ heparin (Stemcell), $0.48 \mu \mathrm{g} / \mathrm{mL}$ hydrocortisone (Stemcell), and $100 \mu \mathrm{g} / \mathrm{mL}$ streptomycin and $100 \mathrm{U} / \mathrm{mL}$ penicillin (Lonza) to the basal compartment to induce differentiation. The cells were differentiated for four weeks on this air-liquid interface. Prior to experiments, the cells were cultured for three days in PneumaCult-ALI Basal Medium without heparin, hydrocortisone, and antibiotics [26].

\subsection{Viruses}

SARS-CoV-2 isolate BetaCoV/Munich/BavPat1/2020 (European Virus Archive no. 026V-03883) was kindly provided by Prof. C. Drosten (Charité-Universitätsmedizin, Berlin Institute of Virology, Berlin, Germany), and it was initially cultured in Vero E6 cells up to three passages in the laboratory of Prof. B. Haagmans (Viroscience Department, Erasmus Medical Center, Rotterdam, The Netherlands). To prepare virus stock, Vero FM cells were infected with passage 3 stock at an MOI of 0.01 in virus infection medium [DMEM (Gibco) containing 2\% FCS (Sigma-Aldrich), $20 \mathrm{mM}$ HEPES buffer (Gibco), $100 \mu \mathrm{g} / \mathrm{mL}$ streptomycin (Gibco), and $100 \mathrm{IU} / \mathrm{mL}$ penicillin (Gibco)]. At $48 \mathrm{~h}$ post infection (hpi), cell culture supernatant was harvested, centrifuged at $4700 \times \mathrm{g}$ for $10 \mathrm{~min}$. at $4{ }^{\circ} \mathrm{C}$ to remove cellular debris, filtered through a $0.2 \mu \mathrm{m}$ syringe filter (Whatman, Maidstone, UK), and then stored as $100 \mu \mathrm{L}$ aliquots at $-80^{\circ} \mathrm{C}$.

Isolate SARS-CoV-2/human/NLD/Nijmegen1/2020 was isolated from an oronasopharyngeal swab of a 65-year old male COVID-19 patient that was hospitalized at Radboud University Medical Center in May 2020, collected as part of an ongoing study on COVID-19 infectiousness and viral kinetics. The Committee on Research Involving Human Subjects Arnhem Nijmegen (CMO NL2020-6517) approved the study and it conducted according to the principles of the Declaration of Helsinki (last updated 2013) and in accordance with the Medical Research Involving Human Subjects Act (Dutch: WMO). Verbal consent was provided at inclusion and separate verbal consent was obtained for the use of isolated virus in additional experiments.

The nasal swab was initially stored in virus transport medium [Hank's Balanced Salt Solution (Gibco) containing 2\% FCS (Sigma-Aldrich), $100 \mu \mathrm{g} / \mathrm{mL}$ gentamycin (Gibco), and $0.5 \mu \mathrm{g} / \mathrm{mL}$ amphotericin-B (Gibco)]. Vero FM cells that were seeded in 24-well plates were infected in duplicate with $100 \mu \mathrm{L}$ two-fold serial dilutions of patient material in a total volume of $200 \mu \mathrm{L}$ using virus isolation medium [DMEM (Gibco) containing, $20 \mathrm{mM}$ HEPES buffer (Gibco), $100 \mu \mathrm{g} / \mathrm{mL}$ streptomycin (Gibco), $100 \mathrm{IU} / \mathrm{mL}$ penicillin (Gibco), $1 \%$ amphotericin B (Gibco)]. After $1 \mathrm{~h}$ adsorption, viral inoculum was discarded, cells were washed with PBS, and $500 \mu \mathrm{L}$ virus isolation medium containing $2 \%$ FCS was added. $100 \mu \mathrm{L}$ of supernatant was collected at two, four, and six days post-infection, subjected to RNA isolation and RT-qPCR to detect SARS-CoV-2 RNA. The rest of the supernatants were stored at $-80{ }^{\circ} \mathrm{C}$. The supernatant from which a positive signal was obtained in RT-qPCR was titrated by conventional plaque assay and it was cultured in Vero FM cells at an MOI of 0.01 to obtain passage 1 working stocks. The near full-length viral sequence of the isolate was deduced by amplicon-based next-generation sequencing [27], supplemented with Sanger sequencing to fill few remaining gaps in the obtained sequence. The sequence has been deposited in GenBank under accession number MW577029 and it was assigned lineage B.1, using the web application of the Pangolin COVID-19 Lineage Assigner (https: / / pangolin.cog-uk.io/, accessed on 07 February 2021) [28]. 


\subsection{Virus Titration}

Vero E6 cells were seeded onto 12-well plates at a density of $5 \times 10^{5}$ cells/well. At $24 \mathrm{~h}$ post-seeding, the cells were washed twice with PBS and then infected with $200 \mu \mathrm{L} 10$-fold serial dilutions of the virus. After $1 \mathrm{~h}$ adsorption, the inoculum was discarded, cells were washed with PBS, and overlay medium containing Minimum essential medium (MEM, Gibco), 2\% FCS (Sigma-Aldrich), 20 mM HEPES buffer (Gibco), $0.75 \%$ carboxymethyl cellulose (Sigma-Aldrich), $100 \mu \mathrm{g} / \mathrm{mL}$ streptomycin, and $100 \mathrm{IU} / \mathrm{mL}$ penicillin (Gibco) was added onto the cells. At $48 \mathrm{hpi}$, the medium was discarded, cells were washed with PBS, and then stained with $0.25 \%$ crystal violet solution containing $4 \%$ formaldehyde for $30 \mathrm{~min}$. The plates were then washed with double-distilled water, dried and plaques were counted.

\subsection{Infection of Primary Nasal Epithelial Cells}

Differentiated primary nasal epithelial cells seeded onto $0.4 \mu \mathrm{m}$ pore polyester membrane inserts (Corning, Corning, NY, USA) were inoculated with SARS-CoV-2 BavPat1 isolate at an MOI of 10 at both the apical and basolateral surfaces. At $2 \mathrm{hpi}$, the inoculum was discarded, cells were washed with PBS, and fresh PneumaCult-ALI Basal Medium (Stemcell) without heparin, hydrocortisone, and antibiotics was added to the basolateral compartment. At the desired time points, $200 \mu \mathrm{L}$ of pre-warmed medium was added to the apical surface of the cells and then incubated for $10 \mathrm{~min}$. at $37^{\circ} \mathrm{C}$. Apical and basolateral supernatants were collected for titration or RNA isolation. Intracellular RNA was isolated using RNA-Solv reagent (Omega Bio-Tek, Norcross, GA) according to the manufacturer's protocols, while using glycogen during precipitation.

\subsection{Antiviral Assays}

BBR (Sigma-Aldrich) and OLX (Selleck Chemicals, Houston, TX) were dissolved in DMSO at a stock concentration of $10 \mathrm{mM}$. Vero E6 cells were seeded onto 24-well plates at a density of $1.5 \times 10^{5}$ cells/well. $24 \mathrm{~h}$ post-seeding, the cells were washed twice with PBS and then infected with the SARS-CoV-2 BavPat1 or Nijmegen1 isolate at an MOI 0.01 in the presence of eight concentrations of a two-fold dilution series of BBR or OLX. As a negative control, $0.1 \%$ DMSO was used, corresponding to the DMSO concentration in cells that were treated with $10 \mu \mathrm{M}$ of compound. At $1 \mathrm{hpi}$, virus inoculum was discarded, cells were washed with PBS and replaced with infection medium containing the same concentrations of the inhibitors. At $24 \mathrm{hpi}$, the cell culture supernatants were collected and stored at $-80^{\circ} \mathrm{C}$ for plaque titration. RNA was isolated from cells or $100 \mu \mathrm{L}$ cell culture supernatant using RNA-Solv reagent (Omega Bio-Tek) and precipitated in the presence of glycogen.

Differentiated primary nasal epithelial cells, which were seeded onto $0.4 \mu \mathrm{m}$ pore polyester membrane inserts (Corning), were infected with SARS-CoV-2 BavPat1 isolate at an MOI of 10 at both the apical and basolateral surfaces in the presence of a two-fold dilution series of BBR or OLX. At $2 \mathrm{hpi}$, the inoculum was discarded, cells were washed with PBS, and fresh PneumaCult-ALI Basal Medium without heparin, hydrocortisone, and antibiotics, containing the same concentrations of BBR or OLX was added to the basolateral compartment. SARS-CoV-2 infection in the presence of $0.1 \%$ DMSO was used as a negative control. At $72 \mathrm{hpi}, 200 \mu \mathrm{L}$ of pre-warmed medium was added to the apical surface of the cells and then incubated for $10 \mathrm{~min}$. at $37^{\circ} \mathrm{C}$ and $200 \mu \mathrm{L}$ was collected for RNA isolation. The effective concentration of compound that reduced viral levels by $50 \%\left(\mathrm{EC}_{50}\right)$ was estimated by four parameter logistic regression, using Graphpad Prism (version 5.0). The selectivity index (SI) was defined as the $\mathrm{CC}_{50} / \mathrm{EC}_{50}$ ratio.

\subsection{Cell Viability Assay}

Vero E6 cells that were seeded in 96-well plates at a density of $3 \times 10^{4}$ cells/well were treated with two-fold dilution series of BBR and OLX in the absence of SARS-CoV-2 infection. Cells treated with $0.1 \%$ DMSO were used as a negative control. At $24 \mathrm{~h}$ post- 
treatment, the cell viability was assessed using the Cell Titer Glo 2.0 kit (Promega, Madison, WI, USA) according to the manufacturer's instructions. Luminescence was detected on the Victor Multilabel Plate Reader (Perkin Elmer, Waltham, MA, USA). The 50\% cytotoxicity concentration $\left(\mathrm{CC}_{50}\right)$ value was estimated by four parameter logistic regression of the data, using Graphpad Prism (version 5.0).

\subsection{Time-of-Addition Assay}

Vero E6 cells were seeded in 24-well plates at a density of $1.5 \times 10^{4}$ cells/well. At $24 \mathrm{~h}$ post-seeding, the cells were washed twice with PBS and then infected with SARS-CoV-2 BavPat1 isolate at an MOI of 1 . At indicated time points during the course of the experiment, $20 \mu \mathrm{M}$ BBR, $0.25 \mu \mathrm{M}$ OLX, or $0.1 \%$ DMSO was added. Cell culture supernatants were collected at 10 hpi and infectious viral titers were analyzed and estimated by plaque assay.

\section{8. $R T-q P C R$}

TaqMan Reverse Transcription reagent and random hexamers (Applied Biosystems, Foster City, CA, USA) were used for cDNA synthesis. Semi-quantitative real-time PCR was performed using GoTaq qPCR Master Mix (Promega, Madison, WI, USA) while using primers targeting the SARS-CoV-2 E protein gene (forward primer, 5'-ACAGGTACGTTAAT AGTTAATAGCGT-3'; reverse primer, 5' -ACAGGTACGTTAATAGTTAATAGCGT-3'). A standard curve of a plasmid containing the E gene qPCR amplicon was used to convert $\mathrm{Ct}$ values to relative genome copy numbers. Human and African green monkey (Chlorocebus sabaeus) $\beta$-actin were used as housekeeping genes for normalization (Human $\beta$-actin, forward primer $5^{\prime}$-CCTTCCTGGGCATGGAGTCCTG-3' , and reverse primer $5^{\prime}$-GGAGCAATGATCTTGATCT TC-3' ; African green monkey $\beta$-actin, forward primer $5^{\prime}$ ATTGGCAATGAGCGGTTCC-3' ${ }^{\prime}$, and reverse primer 5' -CTGTCAGCAATGCCAGGGTA-3').

\subsection{Immunofluorescence Staining}

Primary nasal epithelial cells were mock-infected with PneumaCult-ALI Basal Medium for $2 \mathrm{~h}$ or infected with SARS-CoV-2 BavPat1 isolate at an MOI of 10. Vero E6 cells were infected with SARS-CoV-2 BavPat1 isolate at an MOI of 0.01 or mock-infected for $1 \mathrm{~h}$ at $37^{\circ} \mathrm{C}$, after which the cells were washed with PBS. The primary nasal epithelial cells were fixed with 4\% formaldehyde at 0, 24, 48, 72, and 96 hpi. Vero E6 cells were fixed at 24 hpi. Cells were permeabilized with $0.1 \%$ Triton X-100 for 5 min., blocked with 2\% Normal Serum Block (BioLegend, San Diego, CA, USA), 1\% BSA, and 0.0005\% Triton X-100 in PBS for $30 \mathrm{~min}$. The primary nasal epithelial cells and Vero E6 cells were stained for $1 \mathrm{~h}$ with $0.01 \mathrm{mg} / \mathrm{mL}$ rabbit anti-SARS-CoV-2 Spike S1 subunit (clone\#007, Sino Biologicals, Bejing, China) and $0.03 \mathrm{mg} / \mathrm{mL}$ mouse anti-Tubulin IV (cloneONS.1A6, Sigma) or mouse anti-Muc5AC (clone 45M1, Invitrogen, Carlsbad, CA, USA). Subsequently, the cells were stained for $1 \mathrm{~h}$ with $0.01 \mathrm{mg} / \mathrm{mL}$ goat anti-mouse Dylight 488 (Biolegend), $0.01 \mathrm{mg} / \mathrm{mL}$ donkey anti-rabbit AF555 (Biolegend), and a 1:2000 dilution of phalloidin-iFluor 647 reagent (Abcam). For Figure S1, Vero E6 cells (Figure S1) were stained for $1 \mathrm{~h}$ with anti-SARS-CoV Spike S1 subunit human IgG1 (BEI Resources) and mouse anti-dsRNA J2 monoclonal antibody (Scicons, Szirák, Hungary). Goat anti-mouse Alexa Fluor 568 (Invitrogen) and goat anti-human Alexa Fluor 488 (Invitrogen) were used at 1:500 dilutions for secondary staining. The polyester membrane containing the nasal epithelial cells was cut out of the insert with a scalpel and then placed on a microscopy slide, embedded in ProLong Diamond Antifade Mountant with DAPI (Invitrogen), and covered with a coverslip. Vero E6 that had been grown on coverslips was embedded in the same way. Fluorescent images were made using a Leica Dmi 8 microscope with $20 \times$ and $100 \times$ objectives and Leica CFC7000 GT camera using LAS X 3.4.2 software. Confocal images for Vero E6 cells in Figure S1B were captured using a Zeiss LSM9000 microscope with a $63 \times$ oil objective and then processed using FIJI software. 


\subsection{Cytokine and Chemokine Analysis}

Primary nasal epithelial cells that were cultured on an air-liquid interface were infected with SARS-CoV-2 (BavPat1 isolate) at an MOI of 10 or mock infected. Samples were taken from the basolateral medium over time and the concentration of chemokines and cytokines was determined using the LEGENDplex Human Anti-Virus Response Panel (13-plex) and the LEGENDplex Human Proinflammatory Chemokine Panel (13-plex) on a FACSCanto II flow cytometer (BD). The samples were run in duplicate and measured at two different dilutions.

\section{Results}

\subsection{Berberine and Obatoclax Inhibit SARS-CoV-2 Replication}

BBR and OLX have shown antiviral activity against viruses from multiple families [21-25]. Therefore, we tested these compounds against SARS-CoV-2 in Vero E6 cells. A virus growth curve was performed to determine the optimal time point for the assay. At a low multiplicity of infection (MOI) of 0.01 , SARS-CoV-2 titers peaked at $24 \mathrm{~h}$ post-infection (hpi) (Figure S1A). The robust infection of Vero E6 cells was confirmed through staining infected cells for the presence of dsRNA replication intermediates and the SARS-CoV-2 spike protein. dsRNA staining was observed in the perinuclear area, likely corresponding to the ER-Golgi network containing SARS-CoV-2 replication complexes (Figure S1B). Spike protein expression was also detected in the perinuclear area, where they are synthesized, but also on the outer periphery of the cells, probably from viruses exiting the infected cells.

Next, a dose response assay was carried out under these conditions with a series of concentrations of BBR and OLX, using $0.1 \%$ DMSO as a negative control. Plaque assay titrations of the viral supernatants showed that both BBR and OLX are effective against SARS-CoV-2 with $50 \%$ effective concentration $\left(\mathrm{EC}_{50}\right)$ values at low micromolar and nanomolar concentrations $\left(\mathrm{EC}_{50} \mathrm{BBR}=9.1 \mu \mathrm{M}\right.$ and $\mathrm{EC}_{50} \mathrm{OLX}=67 \mathrm{nM}$, respectively; Figure 1A,B). The cytotoxicity of these compounds was tested under the same conditions, but in the absence of SARS-CoV-2 infection. BBR was only toxic at the highest concentrations tested $\left(50 \%\right.$ cellular cytotoxicity, $\left.\mathrm{CC}_{50}>150 \mu \mathrm{M}\right)$, resulting in a selectivity index of $>16$ (Figure 1C), whereas the $\mathrm{CC}_{50}$ value for OLX was $7.8 \mu \mathrm{M}$ (Figure 1D), corresponding to a high selectivity index of 116 , due to its low $\mathrm{EC}_{50}$ value. Overall, these results indicate that BBR and OLX show potent antiviral activity against SARS-CoV-2 with good selectivity indices.

\subsection{Berberine and Obatoclax Are Effective Against a SARS-Cov-2 Isolate from a Different Geographic Region}

Our initial antiviral assays were performed using a SARS-CoV-2 isolate from Bavaria, Germany (BavPat1). We isolated a SARS-CoV-2 isolate from a hospitalized COVID-19 patient at Radboud University Medical Center, the Netherlands to assess whether BBR and OLX are also effective against another SARS-CoV-2 isolate. This isolate, SARSCoV-2/human/NLD/Nijmegen1/2020 (hereafter called Nijmegen1), had a relatively small plaque phenotype (Figure S2), in agreement with the short passage history in Vero cells $[29,30]$. We used the Nijmegen1 isolate to perform dose response assays with BBR and OLX, using viral RNA in the cell culture supernatants as a readout (Figure 2). OLX showed stronger antiviral activity for the Nijmegen1 isolate $\left(\mathrm{EC}_{50}=<0.04 \mu \mathrm{M}\right)$ (Figure 2B) as compared to the BavPat1 isolate. In contrast, BBR showed relatively weak antiviral activity against the Nijmegen1 isolate $\left(\mathrm{EC}_{50}=23.2 \mu \mathrm{M}\right.$ for viral RNA in the supernatant and $\mathrm{EC}_{50}=43.3 \mu \mathrm{M}$ for intracellular viral RNA; Figure 2A) when compared to the initial experiments in which infectious titers were used as a readout. Therefore, we used conventional plaque assay to assess the antiviral activity of BBR against the SARS-CoV-2 Nijmegen1 isolate. We observed strong antiviral activity $\left(\mathrm{EC}_{50}=2.1 \mu \mathrm{M}\right)($ Figure $2 \mathrm{C})$, which was slightly lower than for the BavPat1 isolate. 
A

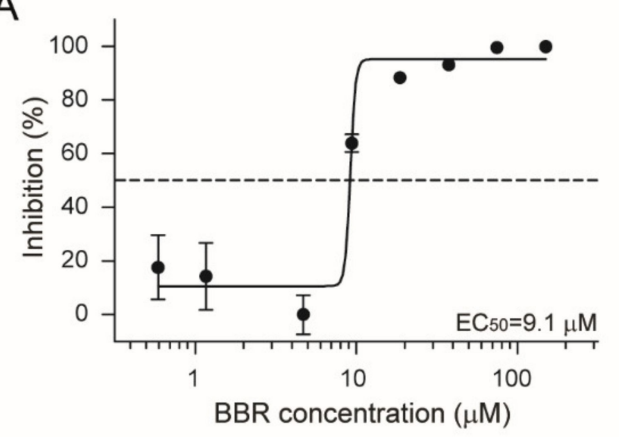

C

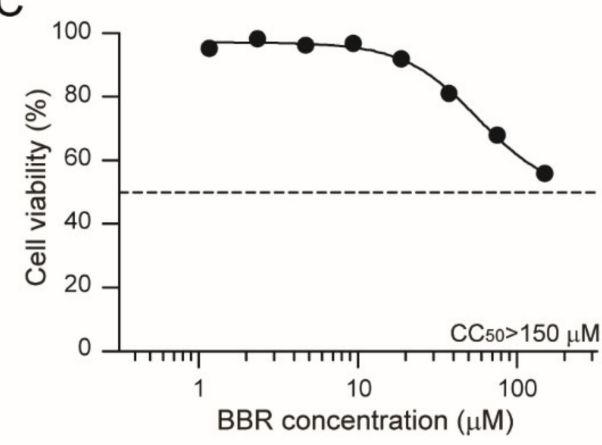

B

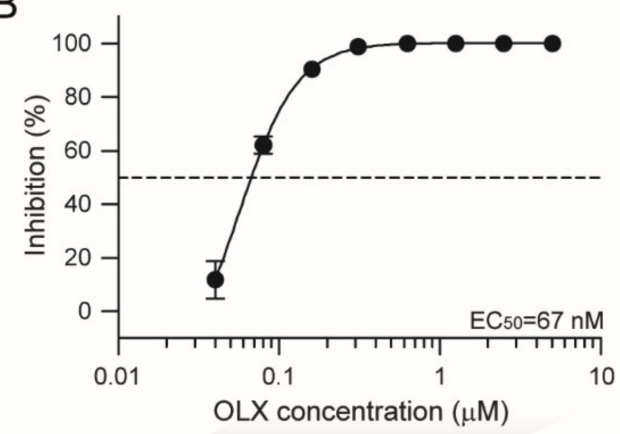

D

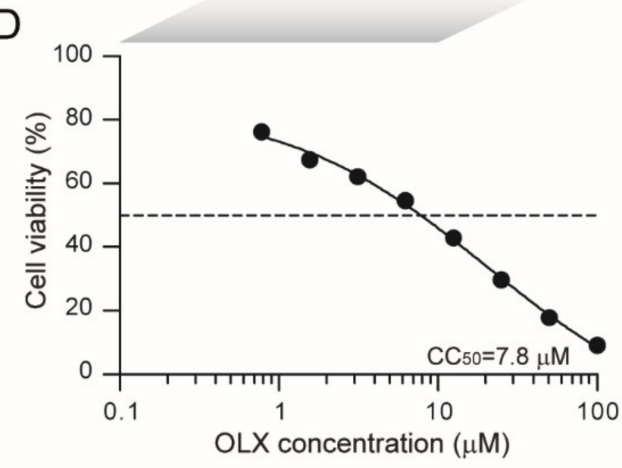

Figure 1. Berberine and obatoclax are effective antiviral compounds against Severe acute respiratory syndrome coronavirus 2 (SARS-CoV-2). Vero E6 cells were infected with SARS-CoV-2 (BavPat1 isolate) at an MOI of 0.01 for $24 \mathrm{~h}$ in the presence of the indicated concentrations of (A) berberine (BBR) or (B) obatoclax (OLX) in a two-fold dilution series or $0.1 \%$ DMSO as a control. Infectious viral titers from duplicate cell culture supernatants were assessed by plaque assay and plotted as percentage inhibition compared to the DMSO control. Error bars indicate SD. Dashed lines indicate 50\% inhibition. A representative of two independent experiments is shown. Vero E6 cells were treated with the indicated concentrations of $(\mathbf{C})$ berberine or (D) obatoclax or 0.1\% DMSO. $24 \mathrm{~h}$ post-treatment, ATP content in cells from triplicate wells was measured as indication for cell viability, plotted as percentage compared to the DMSO control. Error bars indicate SD. A representative of two independent experiments is shown. The shaded grey box indicates that different OLX concentrations were used for antiviral (B) and viability assays (D).

These results suggest that BBR does not inhibit viral RNA replication per se, but that it affects the production of infectious virus. To quantify this, we calculated the relative genome copy to infectious virus particle ratio for the different concentrations of berberine. Indeed, when compared to the DMSO control, this ratio increased upon BBR treatment in a dose-dependent manner (Figure 2D). Altogether, these results confirmed that both BBR and OLX are effective against a second, early passage isolate of SARS-CoV-2. Moreover, we conclude that BBR does not affect viral RNA replication or the secretion of viral particles, but that it strongly affects the infectivity of the virus particles produced.

\subsection{Berberine and Obatoclax Act at Different Stages of The SARS-Cov-2 Life Cycle}

We performed a time-of-addition assay to decipher a putative mode of action for BBR and OLX. Vero E6 cells were infected at an MOI of 1, adding $20 \mu \mathrm{M}$ BBR or $0.25 \mu \mathrm{M}$ OLX at different time points during the course of the experiment (Figure 3A). The cell culture supernatants were harvested at $10 \mathrm{hpi}$ and infectious viral titers were measured by plaque assay. OLX showed a very potent inhibition of three logs at the early stages of the viral life cycle. The levels of inhibition gradually decrease as OLX is added at later time points of the experiment (Figure 3B), which suggests that OLX most likely affects the early stages of the SARS-CoV-2 infection cycle. Indeed, when OLX was added during the $1 \mathrm{~h}$ of virus adsorption and subsequently discontinued, it reduced the viral titers by $1.5 \operatorname{logs}$, indicating that the compound inhibits viral entry. 
A

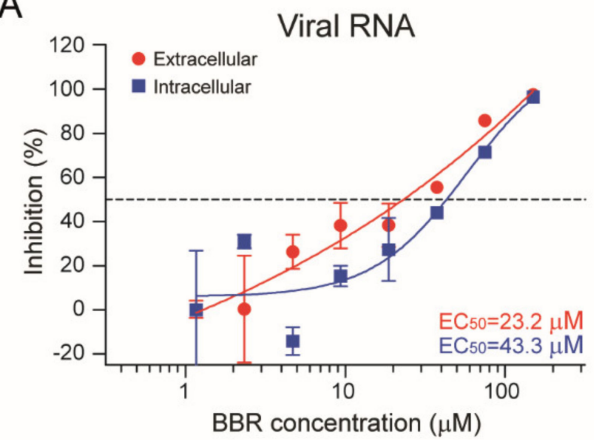

C

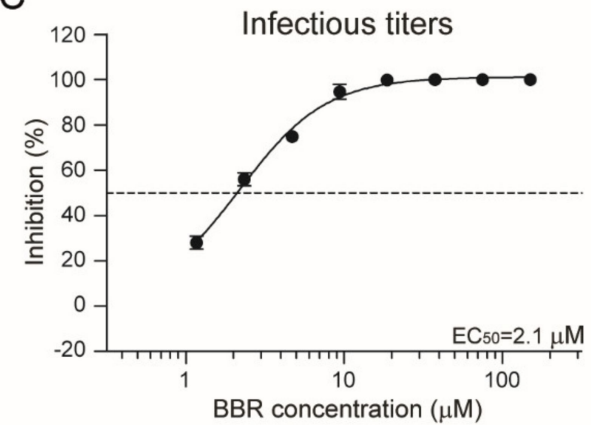

B

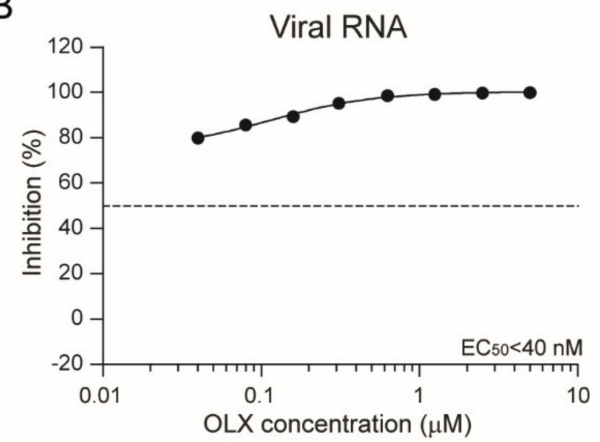

D

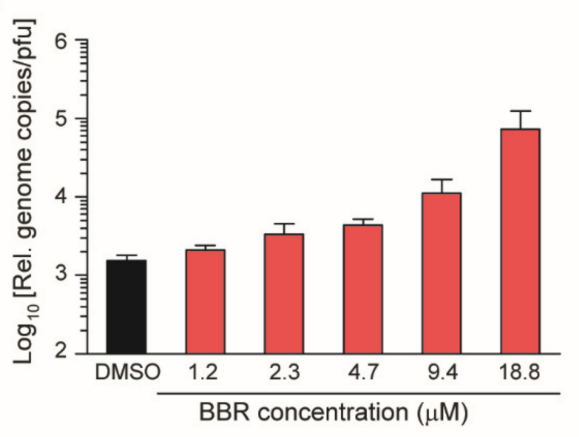

Figure 2. Berberine and obatoclax are effective against SARS-CoV-2 Nijmegen1 isolate. Vero E6 cells were infected with the SARS-CoV-2 Nijmegen1 isolate at an MOI of 0.01 for $24 \mathrm{~h}$ in the presence of the indicated concentrations of (A-C) berberine (BBR) or (B) obatoclax (OLX) in a two-fold dilution series or $0.1 \%$ DMSO as a control. (A,B) Viral RNA from duplicate cell culture supernatants (red line in panel A) was quantified by qRT-PCR and plotted as percentage inhibition compared to the DMSO control. For BBR-treated cells, both extracellular and Intracellular viral RNA was analyzed (red and blue lines, respectively). Intracellular viral RNA levels were normalized to the human $\beta$-actin housekeeping gene. (C) Infectious viral titers from duplicate cell culture supernatants were quantified by plaque assay and plotted as percentage inhibition compared to the DMSO control. Error bars indicate SD. Dashed line indicates 50\% inhibition. (D) The ratio of relative genome copies to infectious viral particles in cell culture supernatants for the indicated, non-toxic BBR concentrations and DMSO control.

For BBR, an inhibition of almost 1.5 logs was seen when the compound was added to the cells $2 \mathrm{~h}$ prior to inoculation and maintained throughout the experiment. However, no inhibition was observed when BBR is only added during the $1 \mathrm{~h}$ of virus adsorption. The potent inhibition of $1 \log$ was observed when BBR was added during inoculation and continuously maintained thereafter. Strikingly, BBR continues to be equally effective at reducing viral titers, even when added at $7.5 \mathrm{hpi}$, indicating that it acts late in the viral infection cycle (Figure 3B), in line with our conclusion that BBR affects the production of infectious virus particles (Figure 2).

\subsection{SARS-CoV-2 Infection of Primary Nasal Epithelial Cells}

Even though SARS-CoV-2 efficiently replicates in Vero E6 cells, these cells are derived from the African green monkey kidney, have a defective interferon pathway [31], and do not express TMPRSS2 [32], and, thus, they are not representative of natural target cells. Therefore, it is essential to validate candidate antiviral compounds in human host cells [14]. Therefore, we cultured and differentiated human nasal epithelial cells, which were residual after surgery, on an air-liquid interface. This approach to mimic the natural environment of the infected host has previously been used for studying circulating seasonal human coronaviruses, such as HCoV-229E, HCoV-OC43, HCoV-NL63, and HCoV-HKU1, as well as the zoonotic SARS and MERS coronaviruses [33]. 

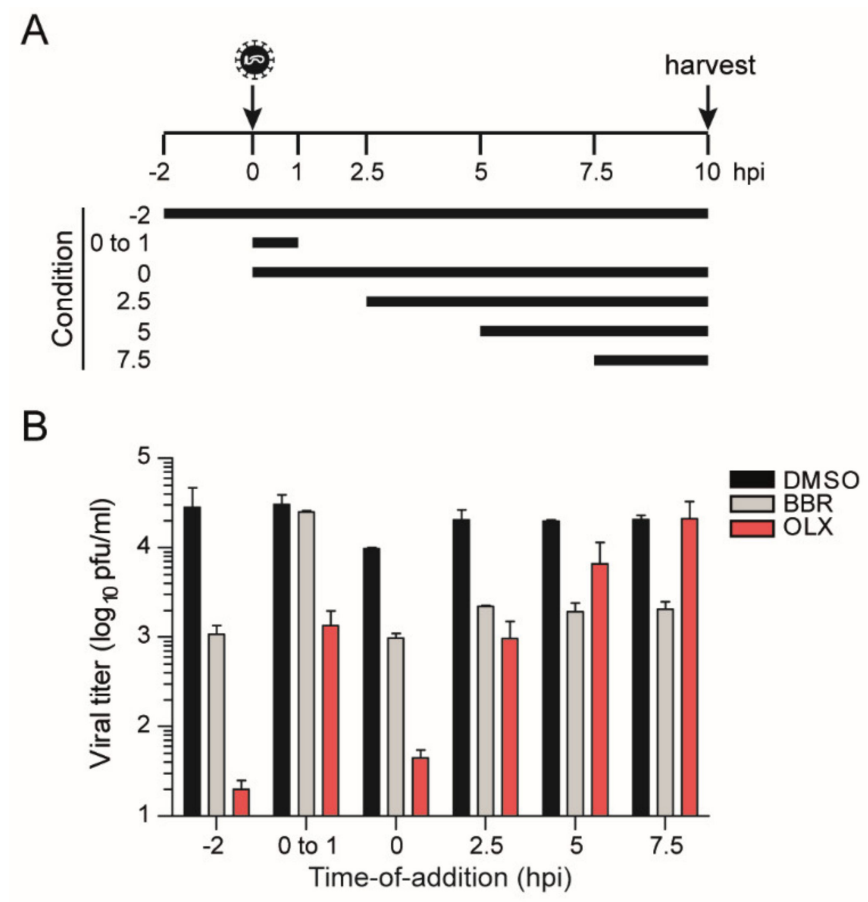

Figure 3. Time-of-addition assay. Vero E6 cells were infected with SARS-CoV-2 (BavPat1 isolate) at an MOI of 1. (A) Schematic layout of the assay. $20 \mu \mathrm{M}$ berberine (BBR), $0.25 \mu \mathrm{M}$ obatoclax (OLX), or $0.1 \%$ DMSO as a control was added to the infected cells at the indicated time points. (B) Plaque assay titers from cell culture supernatants that were collected at $10 \mathrm{hpi}$. Bars and error bars represent means and SD of $\mathrm{n}=2$ replicates.

Virus replication was assessed to determine the optimal time point for antiviral assays. We analyzed intracellular RNA, extracellular RNA from apical and basal supernatants, infectious viral titers, and viral protein expression at different time points post-infection. Peak intracellular viral RNA levels were detected at $72 \mathrm{hpi}$ (Figure 4A). No time-dependent increase in viral RNA levels was observed in basolateral supernatants, which suggested the inefficient release of virus into this compartment. In contrast, viral RNA signals from the apical surface supernatants were at their highest at $72 \mathrm{hpi}$, corresponding to the kinetics of intracellular RNA (Figure 4B). The preferential release from the apical membrane in polarized epithelial cells has been observed before for multiple viruses, including SARS$\mathrm{CoV}$ [34-36]. Infectious viral titers from the apical supernatants also showed active viral replication, with peak titers at 72 hpi (Figure $4 \mathrm{C}$ ) in line with the viral RNA kinetics (Figure 4A,B).

The nasal epithelium contains both ciliated cells and mucus producing goblet cells after four weeks of differentiation on the air-liquid interface (Figure S3). We analyzed SARSCoV-2 spike protein expression by immunofluorescence microscopy to assess infection of these cell types. To validate the anti-Spike protein antibody used, we first analyzed SARS-CoV-2 infected Vero E6 cells and observed abundant S protein expression in the perinuclear area as well as the periphery in order (Figure 4D). In SARS-CoV-2 infected nasal epithelial cells, SARS-CoV-2 S protein was detected from 48-72 hpi onwards (Figure S3). In these cells, the $S$ protein was mostly located at the outer cell periphery and, as expected, at much lower levels than in Vero E6 cells. At $0 \mathrm{hpi}$, some S protein staining is also visible, which likely corresponds to viral particles that have not internalized and remain attached to the cell surface (Figure S3). Additionally, the epithelial cells were stained for the differentiation markers tubulin IV and Muc5Ac to identify ciliated cells and goblet cells, respectively. It did not appear that viral infection was more abundant in either of these cell types (Figure 4D, Figure S3). 
A

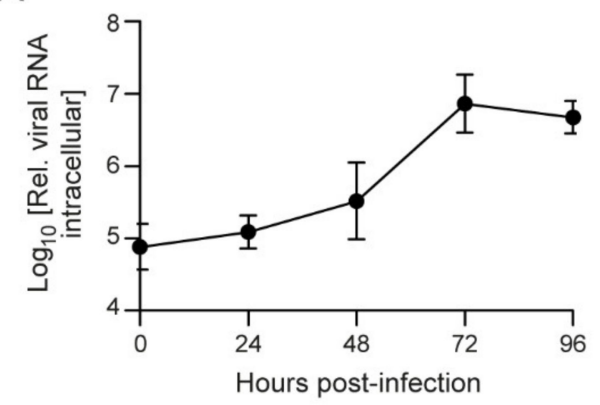

$\mathrm{D}$

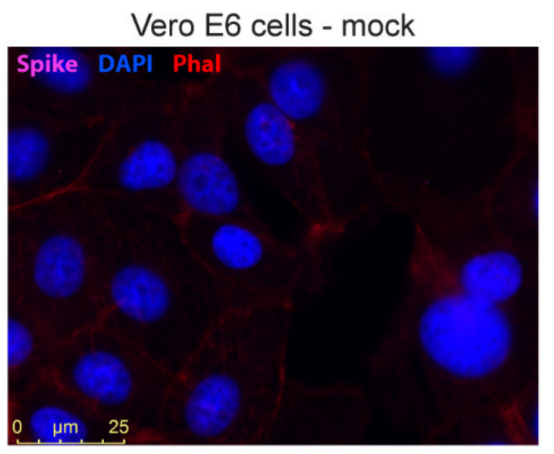

B

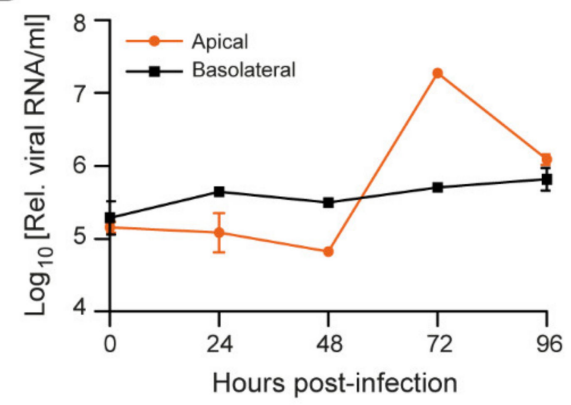

Vero E6 cells - 24 hpi

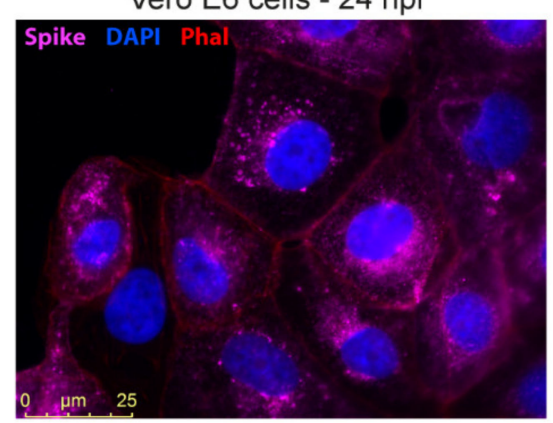

C

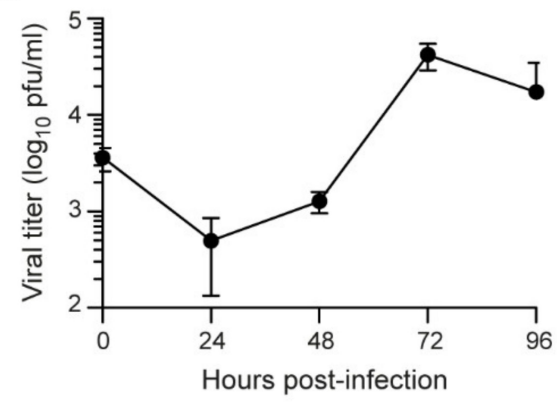

Nasal epithelial cells - 96 hpi

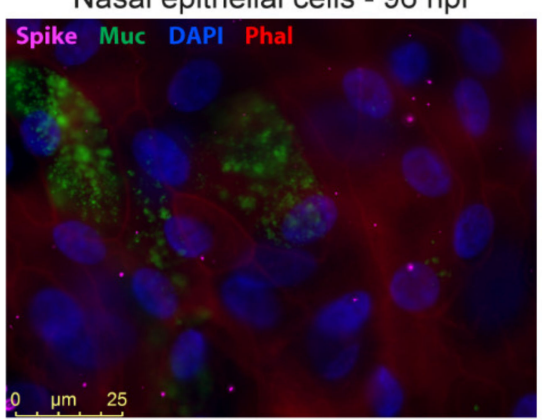

Figure 4. SARS-CoV-2 infection of primary nasal epithelial cells. Primary nasal epithelial cells, cultured on an air-liquid interface, were infected with SARS-CoV-2 (BavPat1 isolate) at an MOI of 10. At the indicated time points, cells were harvested and viral RNA from (A) cells or (B) apical and basolateral compartment supernatants was quantified by RT-qPCR. Intracellular viral RNA levels were normalized to the human $\beta$-actin housekeeping gene. Error bars indicate SD $(n=2)$. $(C)$ Infectious viral titers from apical supernatants corresponding to the indicated time points were quantified by plaque assay. Error bars indicate SD ( $\mathrm{n}=2$ ). (D) Immunofluorescence staining of mock (left panel), SARS-CoV-2 infected Vero E6 cells fixed at $24 \mathrm{hpi}(\mathrm{MOI}=0.01$; middle panel) or SARS-CoV-2 infected primary nasal epithelial cells fixed at $96 \mathrm{hpi}(\mathrm{MOI}=10$; right panel). The presence of SARS-CoV-2 Spike protein subunit S1 (pink) was assessed in cells stained with DAPI (nucleus, blue) and phalloidin (F-actin, red). Nasal epithelial cells were additionally stained with anti-Muc5AC antibodies (Muc, goblet cells, green). Bar represents $25 \mu \mathrm{m}$.

\subsection{Cytokine and Chemokine Responses Are Selectively Enhanced or Inhibited during SARS-Cov-2 Infection of Primary Nasal Epithelial Cells}

We measured cytokine and chemokine concentrations in the cell culture medium of primary nasal epithelial cells that were infected with SARS-CoV-2 from 0 to 96 hpi to assess the epithelial (immune) response to SARS-CoV-2 infection. Cytokines and chemokines that are associated with granulocyte (CXCL1 and CXCL8), monocyte (CXCL10, CCL4, and CCL20), NK cell (CXCL10 and CCL4), and T cell (CCL20, CCL17, and CXCL10) chemotaxis and activation increased over time when compared to the mock infected cells (Figure 5A). CXCL1, CXCL8, CXCL10, CCL4, and CCL20 showed a more rapid production rate between 48 and 96 hpi, which is in line with the viral replication kinetics that we observed (Figure 4), suggesting that viral replication triggers cytokine and chemokine production in these cells. Strikingly, the cytokines that are typically associated with viral infection and acute phase reactions (IL- $1 \beta$, TNF- $\alpha 2$, IL-6, IFN- $\lambda 1$, and IFN- $\lambda 2,3$ ) did not show increased production when compared to mock infected cells, with the exception of IL-1 $\beta$ ( Figures 5A and S4). Furthermore, within the first 48 h of infection, the production of CXCL5, CCL3, CCL5, and, to a lesser extent, GM-CSF, was reduced (Figure 5B). This could be indicative of immune evasive activity of SARS-CoV-2. 

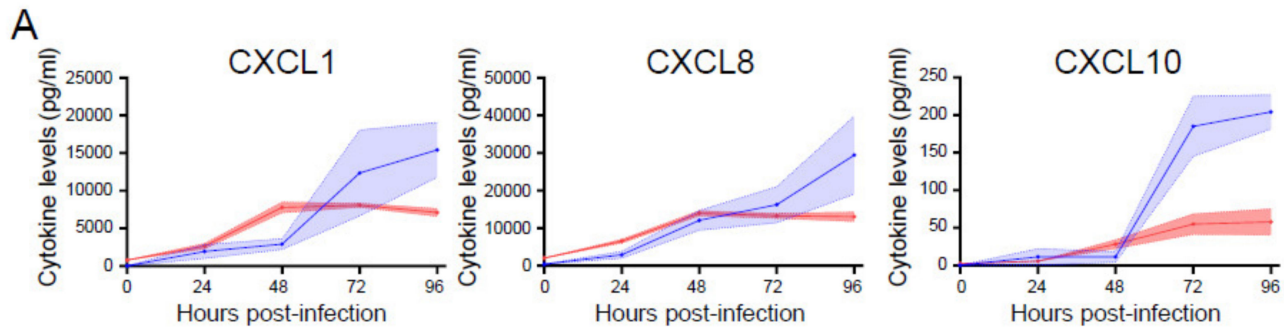

SARS-COV-2 Mock
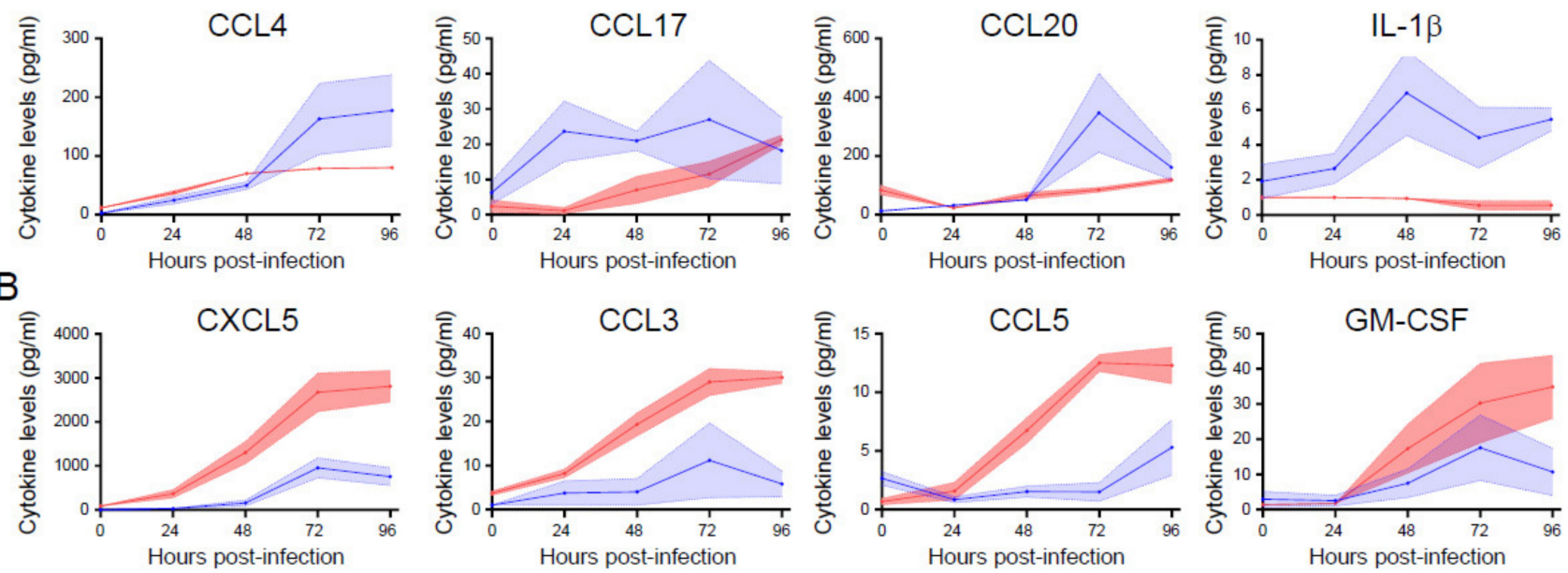

Figure 5. The induction and repression of specific cytokine and chemokines during SARS-CoV-2 infection of primary nasal epithelial cells. Primary nasal epithelial cells cultured on an air-liquid interface were infected with SARS-CoV-2 (BavPat1 isolate) at an MOI of 10 or mock infected. At the indicated time points, medium from the basolateral compartment was harvested and the concentration of the indicated cytokines and chemokines was analyzed by a bead-based immunoassay. Cytokines and chemokines with increased (A) and decreased (B) expression are shown. Means and SEM (shading) of $n=2$ replicates are shown.

These data suggest that the epithelium selectively stimulates cellular immune responses in response to SARS-CoV-2 infection, while the virus may inhibit the secretion of specific cytokines. Both of the processes appear to be selective, as for various other cytokines, no difference in production could be observed between infected cells and mock infected cells (Figure S4). Other cytokines that we tested, such as IFN- $\alpha$, IFN- $\beta$, IL-10, and IL-12p70, were not produced by the epithelium at all (data not shown). Together, these data indicate a specific and dynamic interaction between airway epithelial cells and SARS-CoV-2.

\subsection{Berberine and Obatoclax Are Effective Against SARS-Cov-2 in Nasal Epithelial Cells}

Having established primary nasal epithelial cells as a relevant cellular model for SARSCoV-2 infection, we assessed the antiviral activity of BBR and OBX in these cells. The nasal epithelial cells were infected with SARS-CoV-2 in the presence of increasing concentrations of BBR or OLX, along with DMSO as a negative control, and viral RNA levels were assessed at 72 hpi. BBR was effective in inhibiting SARS-CoV-2 RNA levels in the supernatant of this nasal epithelial cell model with an $\mathrm{EC}_{50}$ value of $10.7 \mu \mathrm{M}$ (Figure $6 \mathrm{~A}$ ), similar to that seen in Vero E6 cells. Likewise, OLX was effective in the sub-micromolar range with an $\mathrm{EC}_{50}$ value of $0.2 \mu \mathrm{M}$. Cytotoxicity assays were done with BBR and OLX over a $72 \mathrm{~h}$ time period. There was a slight increase in toxicity in these cells as compared to the shorter $24 \mathrm{~h}$ exposure period in Vero E6 cells (Figure 6C,D), which resulted in lower selectivity indices for both compounds (SI = 8.1 and 32.7 for BBR and OLX, respectively) than in Vero E6 cells. Altogether, these results indicate that BBR and OLX effectively inhibit SARS-CoV-2 replication in a physiologically relevant human nasal epithelial cell model. 
A

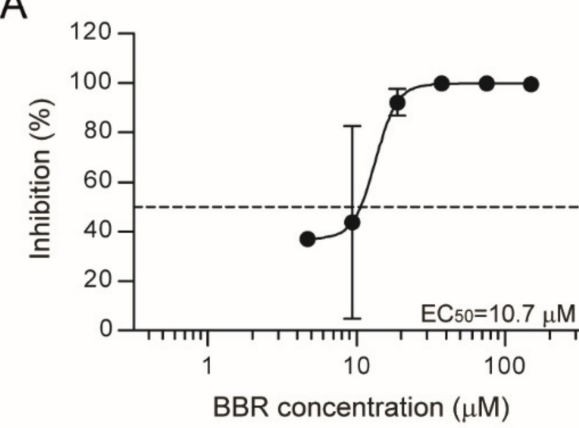

C

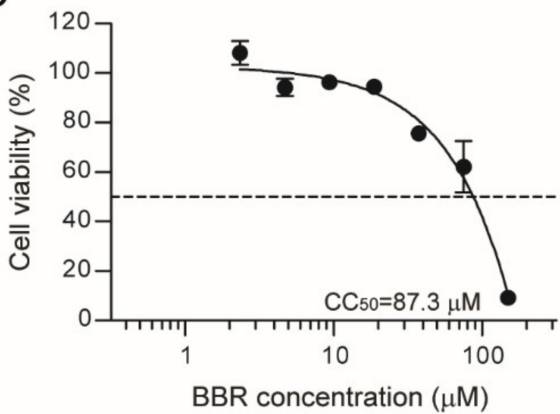

B

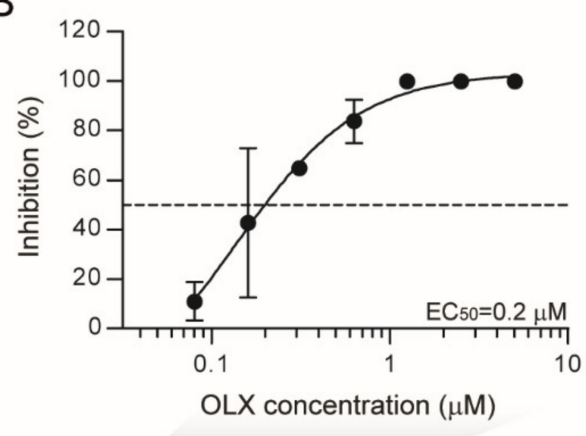

D

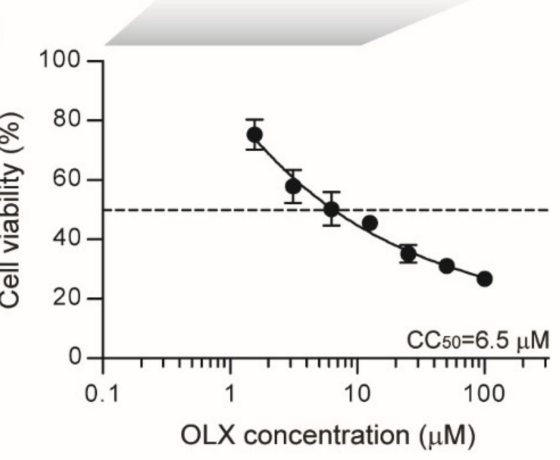

Figure 6. Berberine and obatoclax inhibit SARS-CoV-2 replication in primary nasal epithelial cells. Primary nasal epithelial cells cultured on an air-liquid interface were infected with SARS-CoV-2 (BavPat1 isolate) at an MOI of 10 in the presence of the indicated concentrations of (A) berberine (BBR) or (B) obatoclax (OLX) in a two-fold dilution series or $0.1 \%$ DMSO as a control. Viral RNA from duplicate apical surface supernatants at $72 \mathrm{hpi}$ was quantified by qRT-PCR and plotted as percentage inhibition compared to the DMSO control. Error bars indicate SD $(n=2)$. Dashed line indicates 50\% inhibition. Primary nasal epithelial cells cultured on an air-liquid interface were treated with the indicated concentrations of (C) BBR or (D) OLX or $0.1 \%$ DMSO. At $72 \mathrm{~h}$, the ATP content in cells from duplicate samples was measured as a measure of cell viability, plotted as a percentage of the DMSO control. Error bars indicate SD. Dashed lines indicate 50\% viability. A representative of two independent experiments is shown. The shaded grey box indicates that different OLX concentrations were used for antiviral (B) and viability assays (D).

\section{Discussion}

The COVID-19 pandemic has rapidly spread across the world, causing large-scale morbidity and mortality [5] (WHO Coronavirus Disease Dashboard, (https:/ / covid19.who. int/, accessed on 07 February 2021) and huge economic losses [37]. Effective treatment for patients who fall ill despite vaccination or other preventive measures is urgently needed. In this study, we propose repurposing BBR and OLX, two compounds with good safety profiles in clinical trials, as potential therapeutic options against SARS-CoV-2.

$\mathrm{BBR}$ is an isoquinoline alkaloid that is derived from the Chinese herb Coptis chinensis and plants of the Berberis genus [38]. Its wide-ranging biological properties identified in pre-clinical studies include anti-inflammatory, anti-arrhythmic, antimicrobial [39], and cholesterol-lowering [40] activity. In a large phase IV study randomizing 612 patients, a treatment regimen containing $1000 \mathrm{mg}$ BBR daily was not more effective in treating Helicobacter pylori than a comparator treatment, but it was well tolerated apart from a bitter taste $(20 \%)$ and nausea $(12 \%)$ as the most outspoken side effects [41]. Previous studies also identified a favorable safety profile, with predominantly mild gastrointestinal side effects [42]. BBR has not found a place in clinical practice, but five placebo-controlled clinical trials are currently recruiting patients to study the effect of BBR against a range of conditions, including colorectal adenomas, schizophrenia, and diabetes (ClinicalTrials.gov (accessed on 21 January 2021) Identifiers NCT03281096, NCT03333265, NCT03378934, NCT02808351, NCT02983188, NCT03976336, NCT03198572, and NCT02737943). 
BBR has broad spectrum antiviral activity in vitro against viruses from several different families, including influenza A virus, enterovirus, chikungunya virus, hepatitis B and $C$ viruses, HIV, respiratory syncytial virus, human cytomegalovirus, herpes simplex virus, and human papilloma virus (reviewed in [43]). Here, we show that BBR is effective against SARS-CoV-2 at low micromolar concentrations in Vero E6 cells. While this manuscript was in preparation, our results were confirmed by another study showing the antiviral activity of BBR against SARS-CoV-2 also in Vero E6 cells at a similar EC 50 $_{50}$ value $(10.6 \mu \mathrm{M})$ [44]. Our study adds the validation of this finding in physiologically relevant primary nasal epithelial cells, where BBR is equally effective against SARS-CoV-2. Furthermore, we show that BBR acts late in the viral life cycle and that it likely induces the formation of non-infectious virus particles. Congruently, BBR also inhibited the replication of the alphaviruses Semliki Forest virus and chikungunya virus at a late stage [45], likely by interfering with capsid protein-viral RNA interactions, leading to nucleocapsid assembly or disassembly defects and less infectious viral particles [46]. It remains to be confirmed as to whether BBR has similar effects on assembly of SARS-CoV-2 virions.

In addition to inducing possible assembly affects, BBR may affect cellular pathways to reduce SARS-CoV-2 replication. BBR targets several cellular signaling pathways, including major MAP-kinase pathways (ERK, p38 MAPK, and JNK), as well as the NF- $\mathrm{kB}$ and AMPK/m-TOR signaling pathways [47,48]. Many viruses upregulate these pathways to maximally utilize cellular resources for their replication [49]. The modulation of these pathways by BBR has been implicated in its antiviral activity against several different viruses, including chikungunya virus [23], enterovirus 71 [22], and herpes simplex virus [21]. A recent proteomic analysis of SARS-CoV-2 interaction networks revealed that the p38 MAP kinase pathway was upregulated to counteract the host immune system and that inhibitors targeting this pathway had antiviral activity against SARS-CoV-2 [50]. The modulation of cellular pathways that are needed for productive virus infection could be a second mechanism, through which BBR inhibits SARS-CoV-2 replication.

OLX was originally developed as an inhibitor of Mcl-1, a member of the Bcl-2 family of anti-apoptotic proteins [51]. OLX has been through phase I and II trials for a range of malignancies. Convincing antitumor effects have, thus far, not been demonstrated, but obatoclax proved to be safe in doses of $20-40 \mathrm{mg} / \mathrm{m}^{2}$. The most frequently reported adverse events are dose-related grade 1 or 2 neurological symptoms shortly after infusion [52-57].

OLX has broad-spectrum antiviral activity, employing a mechanism independent of its pro-apoptotic activity. OLX acts as a weak base and it rapidly neutralizes the acidic environment of endosomes and endolysosomes [24]. The acidification of endosomes is required for entry by enveloped viruses of several different families, including SARS-CoV-2 in TMPRSS2-negative target cells (such as Vero cells), where endosomal cathepsin B/L proteases are activated by a drop in endosomal $\mathrm{pH}[7,13,58]$. We found that OLX inhibited SARS-CoV-2 replication at sub-micromolar concentrations in Vero E6 cells $\left(\mathrm{EC}_{50}=0.06 \mu \mathrm{M}\right)$ with a very high selectivity index. This confirms the results of another study, in which OLX was reported to inhibit SARS-CoV-2-induced cytotoxicity in Vero E6 cells [59]. Our time-of-addition assays confirmed the early effect of OLX, in alignment with the expected mechanism of virus entry inhibition. Moreover, we observed antiviral activity in nasal epithelial cells, albeit with a three-fold higher $\mathrm{EC}_{50}$ value than in Vero E6 cells. This is probably due to SARS-CoV-2 entering airway epithelial cells at the plasma membrane, which depends on the cleavage of the viral spike protein by the TMPRSS2 protease, which is $\mathrm{pH}$ independent $[7,58]$. However, unlike chloroquine, which also increases the endosomal $\mathrm{pH}$ but does not inhibit SARS-CoV-2 replication in lung epithelial cells [14], we observed an antiviral effect with OLX. This observation suggests that OLX may affect other steps of the viral life cycle or that SARS-CoV-2 may, at least partly, also enter through the endosomal pathway in our experimental system. In clinical studies where OLX was intravenously administered over $3 \mathrm{~h}$, plasma level concentrations of $\sim 0.4 \mu \mathrm{M}$ were obtained [52,53], suggesting that it would be possible to achieve therapeutic dose levels to treat COVID-19. 
In order to identify candidate antiviral compounds, it is important to assess antiviral activity in physiologically relevant in vitro models, as drug sensitivities may be cell-type specific $[14,60]$. Therefore, we characterized SARS-CoV-2 infection in primary nasal epithelial cells, which are one of the first cells the virus encounters during infection [61]. Expectedly, in these cells with an active innate immune system, SARS-CoV-2 showed lower replication kinetics and reached lower titers than in Vero E6 cells. Still, a robust time-dependent increase in SARS-CoV-2 replication was seen using multiple assessment parameters - viral RNA levels, titers, and viral protein expression. Viral titers that we obtained correspond well to those previously observed in human tracheobronchial epithelial cells grown on an air-liquid interface [62]. In undifferentiated human airway epithelium, reconstituted from human primary nasal cells from a pool of 14 donors, higher SARSCoV-2 titers were observed [63]. In contrast, we used differentiated cells derived from post-operative tissue of a single donor, which may contribute to the observed differences.

SARS-CoV-2 infection of primary nasal epithelial cells induced the epithelial release of CXCL1, CXCL8, CXCL10, CCL4, CCL17, CCL20, and IL1 $\beta$. In contrast, we did not observe an increase in TNF $\alpha$, IL-6, IFN- $\beta$, IFN- $\lambda 1$, and IFN- $\lambda 2,3$, cytokines that are typically involved in antiviral reactions and acute phase induction $[64,65]$. These observations might suggest that epithelial cells recruit leucocytes to the site of infection, rather than initiating an acute phase reaction themselves. Interestingly, viral infection also leads to reduced production of CXCL5, CCL5, CCL3, and GM-CSF, which are mainly involved in the attraction and activation of granulocytes and monocytes [66], suggesting that SARSCoV-2 actively inhibits the recruitment of leukocytes early in infection. In contrast to our findings, Pizzorno et al. observed a minor increase in IL- $1 \beta$ and TNF $\alpha$ mRNA levels, and a larger increase in IFN- $\lambda 1$ and IFN- $\lambda 2,3,4$ mRNA levels in nasal epithelial cells that were infected with SARS-CoV-2 [63]. This discrepancy could be due to several differences in the experimental setup, including the readouts (intracellular RNA versus protein in the supernatant) and the source, anatomical location, and differentiation state of the cells [63].

In conclusion, our study puts forth two small molecule compounds, BBR and OLX, as repurposed antiviral molecules against SARS-CoV-2, in doses lower than that previously shown to be safe in human clinical trials. While OLX is effective at early steps of the viral life cycle, likely interfering with entry processes, BBR acts on the later stages and it likely reduces the infectivity of newly produced virions. BBR and OLX are effective in a physiologically relevant cell culture model at low micromolar concentrations and it could be considered for further assessment.

Supplementary Materials: The following are available online at https: / www.mdpi.com/1999-4 915/13/2/282/s1, Figure S1: SARS-CoV-2 replication kinetics in Vero E6 cells, Figure S2: Plaque phenotype of SARS-CoV2 Nijmegen1 isolate, Figure S3: SARS-CoV-2 spike protein expression in primary nasal epithelial cells, Figure S4: Cytokine and chemokine production from SARS-CoV-2 infected primary nasal epithelial cells.

Author Contributions: Conceptualization, F.S.V. and R.P.v.R.; methodology, E.v.W., M.J.E., G.d.H. and M.I.d.J.; formal analysis, F.S.V., E.v.W., G.J.O. and R.P.v.R.; investigation, F.S.V., E.v.W., G.J.O. and M.J.E.; resources, L.K., N.v.H. and A.v.L.; writing—original draft preparation, F.S.V. and R.P.v.R.; writing-review and editing, F.S.V., E.v.W., L.K., A.v.L., G.d.H., M.I.d.J. and R.P.v.R.; visualization, F.S.V., E.v.W., G.J.O. and R.P.v.R.; supervision, P.M., G.d.H., M.I.d.J. and R.P.v.R.; funding acquisition, R.P.v.R. All authors have read and agreed to the published version of the manuscript.

Funding: This research was funded by a Research Grant from the Human Frontiers Science Foundation, grant number RGP0007/2017) and a VICI grant from the Netherlands Organization for Scientific Research, grant number 016.VICI.170.090) to R.P.v.R.

Institutional Review Board Statement: The SARS-CoV-2 Nijmegen1 isolate was obtained as part of an ongoing study on COVID-19 infectiousness and viral kinetics. The study was conducted according to the guidelines of the Declaration of Helsinki and the Medical Research Involving Human Subjects Act (Dutch: WMO), and approved by The Committee on Research Involving Human Subjects Arnhem Nijmegen (CMO NL2020-6517). 
Informed Consent Statement: Informed consent was obtained from all subjects involved in the study.

Data Availability Statement: The data generated in this study are included in the publication and its Supplementary Materials.

Acknowledgments: We thank Jordy Coolen (Radboud University Medical Center) for help with sequencing the SARS-CoV-2 Nijmegen1 isolate. We thank Christian Drosten (Charité-Universitätsmedizin Berlin, Institute of Virology, Berlin, Germany) and Bart Haagmans (Viroscience Department, Erasmus Medical Center, Rotterdam, The Netherlands) for providing SARS-CoV-2 (isolate BetaCoV/Munich/ BavPat1/2020), and Kjerstin Lanke (Radboud University Medical Center) for providing the plasmid used as standard curve in the GPCR. The following reagent was obtained through BEI Resources, NIAID, NIH: Monoclonal Anti-SARS Coronavirus Recombinant Human IgG1, Clone CR3022 (catalog number NR-52392).

Conflicts of Interest: The authors declare no conflict of interest.

\section{References}

1. Gorbalenya, A.E.; Enjuanes, L.; Ziebuhr, J.; Snijder, E.J. Nidovirales: Evolving the largest RNA virus genome. Virus Res. 2006, 117, 17-37. [CrossRef]

2. Li, W.; Shi, Z.; Yu, M.; Ren, W.; Smith, C.; Epstein, J.H.; Wang, H.; Crameri, G.; Hu, Z.; Zhang, H.; et al. Bats Are Natural Reservoirs of SARS-Like Coronaviruses. Science 2005, 310, 676. [CrossRef] [PubMed]

3. Li, W.; Wong, S.-K.; Li, F.; Kuhn, J.H.; Huang, I.C.; Choe, H.; Farzan, M. Animal Origins of the Severe Acute Respiratory Syndrome Coronavirus: Insight from ACE2-S-Protein Interactions. J. Virol. 2006, 80, 4211. [CrossRef]

4. Mohd, H.A.; Al-Tawfiq, J.A.; Memish, Z.A. Middle East Respiratory Syndrome Coronavirus (MERS-CoV) origin and animal reservoir. Virol. J. 2016, 13, 87. [CrossRef]

5. Dong, E.; Du, H.; Gardner, L. An interactive web-based dashboard to track COVID-19 in real time. Lancet Infect. Dis. 2020, 20, 533-534. [CrossRef]

6. Wu, S.L.; Mertens, A.N.; Crider, Y.S.; Nguyen, A.; Pokpongkiat, N.N.; Djajadi, S.; Seth, A.; Hsiang, M.S.; Colford, J.M., Jr.; Reingold, A.; et al. Substantial underestimation of SARS-CoV-2 infection in the United States. Nat. Commun. 2020, $11,4507$. [CrossRef] [PubMed]

7. Hoffmann, M.; Kleine-Weber, H.; Schroeder, S.; Krüger, N.; Herrler, T.; Erichsen, S.; Schiergens, T.S.; Herrler, G.; Wu, N.-H.; Nitsche, A.; et al. SARS-CoV-2 Cell Entry Depends on ACE2 and TMPRSS2 and Is Blocked by a Clinically Proven Protease Inhibitor. Cell 2020, 181, 271-280.e8. [CrossRef]

8. Wrapp, D.; Wang, N.; Corbett, K.S.; Goldsmith, J.A.; Hsieh, C.-L.; Abiona, O.; Graham, B.S.; McLellan, J.S. Cryo-EM structure of the 2019-nCoV spike in the prefusion conformation. Science 2020, 367, 1260. [CrossRef]

9. Jaimes, J.A.; Millet, J.K.; Whittaker, G.R. Proteolytic Cleavage of the SARS-CoV-2 Spike Protein and the Role of the Novel S1/S2 Site. Science 2020, 23, 101212.

10. Coutard, B.; Valle, C.; de Lamballerie, X.; Canard, B.; Seidah, N.G.; Decroly, E. The spike glycoprotein of the new coronavirus 2019-nCoV contains a furin-like cleavage site absent in CoV of the same clade. Antivir. Res. 2020, 176, 104742. [CrossRef] [PubMed]

11. Inoue, Y.; Tanaka, N.; Tanaka, Y.; Inoue, S.; Morita, K.; Zhuang, M.; Hattori, T.; Sugamura, K. Clathrin-Dependent Entry of Severe Acute Respiratory Syndrome Coronavirus into Target Cells Expressing ACE2 with the Cytoplasmic Tail Deleted. J. Virol. 2007, 81, 8722. [CrossRef]

12. Burkard, C.; Verheije, M.H.; Wicht, O.; van Kasteren, S.I.; van Kuppeveld, F.J.; Haagmans, B.L.; Pelkmans, L.; Rottier, P.J.M.; Bosch, B.J.; de Haan, C.A.M. Coronavirus Cell Entry Occurs through the Endo-/Lysosomal Pathway in a Proteolysis-Dependent Manner. PLoS Pathog. 2014, 10, e1004502. [CrossRef]

13. Shang, J.; Wan, Y.; Luo, C.; Ye, G.; Geng, Q.; Auerbach, A.; Li, F. Cell entry mechanisms of SARS-CoV-2. Proc. Natl. Acad. Sci. USA 2020, 117, 11727. [CrossRef]

14. Hoffmann, M.; Mösbauer, K.; Hofmann-Winkler, H.; Kaul, A.; Kleine-Weber, H.; Krüger, N.; Gassen, N.C.; Müller, M.A.; Drosten, C.; Pöhlmann, S. Chloroquine does not inhibit infection of human lung cells with SARS-CoV-2. Nature 2020, 585, 588-590. [CrossRef] [PubMed]

15. Fehr, A.R.; Perlman, S. Coronaviruses: An overview of their replication and pathogenesis. Methods Mol. Biol. 2015, 1282, 1-23.

16. V'Kovski, P.; Kratzel, A.; Steiner, S.; Stalder, H.; Thiel, V. Coronavirus biology and replication: Implications for SARS-CoV-2. Nat. Rev. Microbiol. 2020. epub ahead of print. [CrossRef] [PubMed]

17. De Wit, E.; van Doremalen, N.; Falzarano, D.; Munster, V.J. SARS and MERS: Recent insights into emerging coronaviruses. Nat. Rev. Microbiol 2016, 14, 523-534. [CrossRef] [PubMed]

18. Wiersinga, W.J.; Rhodes, A.; Cheng, A.C.; Peacock, S.J.; Prescott, H.C. Pathophysiology, Transmission, Diagnosis, and Treatment of Coronavirus Disease 2019 (COVID-19): A Review. JAMA 2020, 324, 782-793. [CrossRef] [PubMed]

19. Krammer, F. SARS-CoV-2 vaccines in development. Nature 2020, 586, 516-527. [CrossRef] 
20. RECOVERY Collaborative Group; Horby, P.; Lim, W.S.; Emberson, J.R.; Mafham, M.; Bell, J.L.; Linsell, L.; Staplin, N.; Brightling, C.; Ustianowski, A.; et al. Dexamethasone in Hospitalized Patients with Covid-19-Preliminary Report. N. Engl. J. Med. 2020. epub ahead of print.

21. Song, S.; Qiu, M.; Chu, Y.; Chen, D.; Wang, X.; Su, A.; Wu, Z. Downregulation of Cellular c-Jun N-Terminal Protein Kinase and NF-кB Activation by Berberine May Result in Inhibition of Herpes Simplex Virus Replication. Antimicrob. Agents Chemother. 2014, 58, 5068. [CrossRef] [PubMed]

22. Wang, H.; Li, K.; Ma, L.; Wu, S.; Hu, J.; Yan, H.; Jiang, J.; Li, Y. Berberine inhibits enterovirus 71 replication by downregulating the MEK/ERK signaling pathway and autophagy. Virol. J. 2017, 14, 2. [CrossRef]

23. Varghese, F.S.; Thaa, B.; Amrun, S.N.; Simarmata, D.; Rausalu, K.; Nyman, T.A.; Merits, A.; McInerney, G.M.; Ng, L.F.P.; Ahola, T. The Antiviral Alkaloid Berberine Reduces Chikungunya Virus-Induced Mitogen-Activated Protein Kinase Signaling. J. Virol. 2016, 90, 9743. [CrossRef]

24. Varghese, F.S.; Rausalu, K.; Hakanen, M.; Saul, S.; Kümmerer, B.M.; Susi, P.; Merits, A.; Ahola, T. Obatoclax Inhibits Alphavirus Membrane Fusion by Neutralizing the Acidic Environment of Endocytic Compartments. Antimicrob. Agents Chemother. 2017, 61, e02227-16. [CrossRef] [PubMed]

25. Andersen, P.I.; Krpina, K.; Ianevski, A.; Shtaida, N.; Jo, E.; Yang, J.; Koit, S.; Tenson, T.; Hukkanen, V.; Anthonsen, M.W.; et al. Novel Antiviral Activities of Obatoclax, Emetine, Niclosamide, Brequinar, and Homoharringtonine. Viruses 2019, 11, 964. [CrossRef] [PubMed]

26. Tandon, R.; Sharp, J.S.; Zhang, F.; Pomin, V.H.; Ashpole, N.M.; Mitra, D.; Jin, W.; Liu, H.; Sharma, P.; Linhardt, R.J. Effective Inhibition of SARS-CoV-2 Entry by Heparin and Enoxaparin Derivatives. J. Virol. 2021, 95, e01987-20. [CrossRef]

27. Wolters, F.; Coolen, J.P.M.; Tostmann, A.; van Groningen, L.F.J.; Bleeker-Rovers, C.P.; Tan, E.C.T.H.; van der Geest-Blankert, N.; Hautvast, J.L.A.; Hopman, J.; Wertheim, H.F.L.; et al. Novel SARS-CoV-2 Whole-genome sequencing technique using Reverse Complement PCR enables easy, fast and accurate outbreak analysis in hospital and community settings. bioRxiv 2020. [CrossRef]

28. Rambaut, A.; Holmes, E.C.; O’Toole, A.; Hill, V.; McCrone, J.T.; Ruis, C.; du Plessis, L.; Pybus, O.G. A dynamic nomenclature proposal for SARS-CoV-2 lineages to assist genomic epidemiology. Nat. Microbiol. 2020, 5, 1403-1407. [CrossRef]

29. Davidson, A.D.; Williamson, M.K.; Lewis, S.; Shoemark, D.; Carroll, M.W.; Heesom, K.J.; Zambon, M.; Ellis, J.; Lewis, P.A.; Hiscox, J.A.; et al. Characterisation of the transcriptome and proteome of SARS-CoV-2 reveals a cell passage induced in-frame deletion of the furin-like cleavage site from the spike glycoprotein. Gen. Med. 2020, 12, 68. [CrossRef] [PubMed]

30. Ogando, N.S.; Dalebout, T.J.; Zevenhoven-Dobbe, J.C.; Limpens, R.; van der Meer, Y.; Caly, L.; Druce, J.; de Vries, J.J.C.; Kikkert, M.; Barcena, M.; et al. SARS-coronavirus-2 replication in Vero E6 cells: Replication kinetics, rapid adaptation and cytopathology. J. Gen. Virol. 2020, 101, 925-940. [CrossRef]

31. Emeny, J.M.; Morgan, M.J. Regulation of the Interferon System-Evidence That Vero Cells Have a Genetic Defect in InterferonProduction. J. Gen. Virol. 1979, 43, 247-252. [CrossRef]

32. Shirogane, Y.; Takeda, M.; Iwasaki, M.; Ishiguro, N.; Takeuchi, H.; Nakatsu, Y.; Tahara, M.; Kikuta, H.; Yanagi, Y. Efficient multiplication of human metapneumovirus in Vero cells expressing the transmembrane serine protease TMPRSS2. J. Virol. 2008, 82, 8942-8946. [CrossRef]

33. Jonsdottir, H.R.; Dijkman, R. Coronaviruses and the human airway: A universal system for virus-host interaction studies. Virol. J. 2016, 13, 24. [CrossRef]

34. Tucker, S.P.; Thornton, C.L.; Wimmer, E.; Compans, R.W. Vectorial release of poliovirus from polarized human intestinal epithelial cells. J. Virol. 1993, 67, 4274-4282. [CrossRef] [PubMed]

35. Katoh, H.; Nakatsu, Y.; Kubota, T.; Sakata, M.; Takeda, M.; Kidokoro, M. Mumps Virus Is Released from the Apical Surface of Polarized Epithelial Cells, and the Release Is Facilitated by a Rab11-Mediated Transport System. J. Virol. 2015, 89, 12026-12034. [CrossRef]

36. Tseng, C.T.; Tseng, J.; Perrone, L.; Worthy, M.; Popov, V.; Peters, C.J. Apical entry and release of severe acute respiratory syndrome-associated coronavirus in polarized Calu-3 lung epithelial cells. J. Virol. 2005, 79, 9470-9479. [CrossRef]

37. Lenzen, M.; Li, M.; Malik, A.; Pomponi, F.; Sun, Y.-Y.; Wiedmann, T.; Faturay, F.; Fry, J.; Gallego, B.; Geschke, A.; et al. Global socio-economic losses and environmental gains from the Coronavirus pandemic. PLoS ONE 2020, 15, e0235654. [CrossRef] [PubMed]

38. Neag, M.A.; Mocan, A.; Echeverría, J.; Pop, R.M.; Bocsan, C.I.; Crişan, G.; Buzoianu, A.D. Berberine: Botanical Occurrence, Traditional Uses, Extraction Methods, and Relevance in Cardiovascular, Metabolic, Hepatic, and Renal Disorders. Front. Pharmacol. 2018, 9, 557. [CrossRef]

39. Chu, M.; Zhang, M.-b.; Liu, Y.-c.; Kang, J.-r.; Chu, Z.-y.; Yin, K.-1.; Ding, L.-y.; Ding, R.; Xiao, R.--x.; Yin, Y.-N.; et al. Role of Berberine in the Treatment of Methicillin-Resistant Staphylococcus aureus Infections. Sci. Rep. 2016, 6, 24748. [CrossRef] [PubMed]

40. Song, D.; Hao, J.; Fan, D. Biological properties and clinical applications of berberine. Front. Med. 2020, 14, 564-582. [CrossRef]

41. Zhang, D.; Ke, L.; Ni, Z.; Chen, Y.; Zhang, L.H.; Zhu, S.H.; Li, C.J.; Shang, L.; Liang, J.; Shi, Y.Q. Berberine containing quadruple therapy for initial Helicobacter pylori eradication: An open-label randomized phase IV trial. Medicine 2017, 96, e7697. [CrossRef]

42. Kumar, A.; Ekavali; Chopra, K.; Mukherjee, M.; Pottabathini, R.; Dhull, D.K. Current knowledge and pharmacological profile of berberine: An update. Eur. J. Pharmacol. 2015, 761, 288-297. [CrossRef] [PubMed]

43. Warowicka, A.; Nawrot, R.; Goździcka-Józefiak, A. Antiviral activity of berberine. Arch. Virol. 2020, 165, 1935-1945. [CrossRef] 
44. Pizzorno, A.; Padey, B.; Dubois, J.; Julien, T.; Traversier, A.; Dulière, V.; Brun, P.; Lina, B.; Rosa-Calatrava, M.; Terrier, O. In vitro evaluation of antiviral activity of single and combined repurposable drugs against SARS-CoV-2. Antivir. Res. 2020, 181, 104878. [CrossRef] [PubMed]

45. Varghese, F.S.; Kaukinen, P.; Gläsker, S.; Bespalov, M.; Hanski, L.; Wennerberg, K.; Kümmerer, B.M.; Ahola, T. Discovery of berberine, abamectin and ivermectin as antivirals against chikungunya and other alphaviruses. Antivir. Res. 2016, 126, 117-124. [CrossRef] [PubMed]

46. Wan, J.J.; Brown, R.S.; Kielian, M. Berberine Chloride is an Alphavirus Inhibitor That Targets Nucleocapsid Assembly. mBio 2020, 11, e01382-20. [CrossRef]

47. Farooqi, A.A.; Qureshi, M.Z.; Khalid, S.; Attar, R.; Martinelli, C.; Sabitaliyevich, U.Y.; Nurmurzayevich, S.B.; Taverna, S.; Poltronieri, P.; Xu, B. Regulation of Cell Signaling Pathways by Berberine in Different Cancers: Searching for Missing Pieces of an Incomplete Jig-Saw Puzzle for an Effective Cancer Therapy. Cancers 2019, 11, 478. [CrossRef]

48. Chen, X.-W.; Di, Y.M.; Zhang, J.; Zhou, Z.-W.; Li, C.G.; Zhou, S.-F. Interaction of Herbal Compounds with Biological Targets: A Case Study with Berberine. Sci. World J. 2012, 2012, 708292. [CrossRef]

49. Stephan, P. RNA viruses and the mitogenic Raf/MEK/ERK signal transduction cascade. Biol. Chem. 2008, 389, $1273-1282$.

50. Bouhaddou, M.; Memon, D.; Meyer, B.; White, K.M.; Rezelj, V.V.; Correa Marrero, M.; Polacco, B.J.; Melnyk, J.E.; Ulferts, S.; Kaake, R.M.; et al. The Global Phosphorylation Landscape of SARS-CoV-2 Infection. Cell 2020, 182, 685-712.e19. [CrossRef] [PubMed]

51. Nguyen, M.; Marcellus, R.C.; Roulston, A.; Watson, M.; Serfass, L.; Murthy Madiraju, S.R.; Goulet, D.; Viallet, J.; Bélec, L.; Billot, X.; et al. Small molecule obatoclax (GX15-070) antagonizes MCL-1 and overcomes MCL-1-mediated resistance to apoptosis. Proc. Natl. Acad. Sci. USA 2007, 104, 19512. [CrossRef]

52. Goard, C.A.; Schimmer, A.D. An evidence-based review of obatoclax mesylate in the treatment of hematological malignancies. Core Evid. 2013, 8, 15-26. [CrossRef]

53. Hwang, J.J.; Kuruvilla, J.; Mendelson, D.; Pishvaian, M.J.; Deeken, J.F.; Siu, L.L.; Berger, M.S.; Viallet, J.; Marshall, J.L. Phase I Dose Finding Studies of Obatoclax (GX15-070), a Small Molecule Pan-BCL-2 Family Antagonist, in Patients with Advanced Solid Tumors or Lymphoma. Clin. Cancer Res. 2010, 16, 4038. [CrossRef]

54. Brown, J.R.; Tesar, B.; Yu, L.; Werner, L.; Takebe, N.; Mikler, E.; Reynolds, H.M.; Thompson, C.; Fisher, D.C.; Neuberg, D.; et al. Obatoclax in combination with fludarabine and rituximab is well-tolerated and shows promising clinical activity in relapsed chronic lymphocytic leukemia. Leuk Lymphoma 2015, 56, 3336-3342. [CrossRef]

55. Chiappori, A.A.; Schreeder, M.T.; Moezi, M.M.; Stephenson, J.J.; Blakely, J.; Salgia, R.; Chu, Q.S.; Ross, H.J.; Subramaniam, D.S.; Schnyder, J.; et al. A phase I trial of pan-Bcl-2 antagonist obatoclax administered as a 3-h or a 24-h infusion in combination with carboplatin and etoposide in patients with extensive-stage small cell lung cancer. Br. J. Cancer 2012, 106, 839-845. [CrossRef]

56. Schimmer, A.D.; Raza, A.; Carter, T.H.; Claxton, D.; Erba, H.; DeAngelo, D.J.; Tallman, M.S.; Goard, C.; Borthakur, G. A multicenter phase I/II study of obatoclax mesylate administered as a 3- or 24-hour infusion in older patients with previously untreated acute myeloid leukemia. PLoS ONE 2014, 9, e108694. [CrossRef] [PubMed]

57. Langer, C.J.; Albert, I.; Ross, H.J.; Kovacs, P.; Blakely, L.J.; Pajkos, G.; Somfay, A.; Zatloukal, P.; Kazarnowicz, A.; Moezi, M.M.; et al. Randomized phase II study of carboplatin and etoposide with or without obatoclax mesylate in extensive-stage small cell lung cancer. Lung Cancer 2014, 85, 420-428. [CrossRef]

58. Sungnak, W.; Huang, N.; Bécavin, C.; Berg, M.; Queen, R.; Litvinukova, M.; Talavera-López, C.; Maatz, H.; Reichart, D.; Sampaziotis, F.; et al. SARS-CoV-2 entry factors are highly expressed in nasal epithelial cells together with innate immune genes. Nat. Med. 2020, 26, 681-687. [CrossRef] [PubMed]

59. Ianevski, A.; Yao, R.; Fenstad, M.H.; Biza, S.; Zusinaite, E.; Reisberg, T.; Lysvand, H.; Loseth, K.; Landsem, V.M.; Malmring, J.F.; et al. Potential Antiviral Options against SARS-CoV-2 Infection. Viruses 2020, 12, 642. [CrossRef] [PubMed]

60. Dittmar, M.; Lee, J.S.; Whig, K.; Segrist, E.; Li, M.; Jurado, K.; Samby, K.; Ramage, H.; Schultz, D.; Cherry, S. Drug repurposing screens reveal FDA approved drugs active against SARS-Cov-2. bioRxiv 2020. [CrossRef]

61. Ziegler, C.G.K.; Allon, S.J.; Nyquist, S.K.; Mbano, I.M.; Miao, V.N.; Tzouanas, C.N.; Cao, Y.; Yousif, A.S.; Bals, J.; Hauser, B.M.; et al. SARS-CoV-2 Receptor ACE2 Is an Interferon-Stimulated Gene in Human Airway Epithelial Cells and Is Detected in Specific Cell Subsets across Tissues. Cell 2020, 181, 1016-1035.e19. [CrossRef]

62. Zhu, N.; Wang, W.; Liu, Z.; Liang, C.; Wang, W.; Ye, F.; Huang, B.; Zhao, L.; Wang, H.; Zhou, W.; et al. Morphogenesis and cytopathic effect of SARS-CoV-2 infection in human airway epithelial cells. Nat. Commun. 2020, 11, 3910. [CrossRef] [PubMed]

63. Pizzorno, A.; Padey, B.; Julien, T.; Trouillet-Assant, S.; Traversier, A.; Errazuriz-Cerda, E.; Fouret, J.; Dubois, J.; Gaymard, A.; Lescure, F.-X.; et al. Characterization and Treatment of SARS-CoV-2 in Nasal and Bronchial Human Airway Epithelia. Cell Rep. Med. 2020, 1, 100059. [CrossRef]

64. Mills, P.R.; Davies, R.J.; Devalia, J.L. Airway epithelial cells, cytokines, and pollutants. Am. J. Resp. Crit. Care 1999, 160, S38-S43. [CrossRef] [PubMed]

65. Ank, N.; Paludan, S.R. Type III IFNs: New layers of complexity in innate antiviral immunity. Biofactors 2009, 35, 82-87. [CrossRef] [PubMed]

66. Vareille, M.; Kieninger, E.; Edwards, M.R.; Regamey, N. The airway epithelium: Soldier in the fight against respiratory viruses. Clin. Microbiol. Rev. 2011, 24, 210-229. [CrossRef] 